九州大学学術情報リポジトリ

Kyushu University Institutional Repository

Increase in Raw Milk Demand and Its Long-Run Effects on Dairy Industrial Organization in Taiwan-An Approach with Spatial Equilibrium Analys is-

Lin, Lily

Department of Agricultural Economies, Facluty of Agriculture, Kyushu University

Kawaguchi, Tsunemasa

Department of Agricultural Economies, Facluty of Agriculture, Kyushu University

https://doi.org/10.5109/24298

出版情報：九州大学大学院農学研究院紀要. 43 (3/4)，pp.509-529，1999-02. Kyushu University バージョン：

権利関係 : 


\title{
Increase in Raw Milk Demand and Its Long-Run Effects on Dairy Industrial Organization in Taiwan-An Approach with Spatial Equilibrium Analysis-
}

\author{
Lily Lin and Tsunemasa Kawaguchi \\ Department of Agricultural Economics, Faculty of Agriculture \\ Kyushu University, Fukuoka 812-8581, Japan \\ (Received October 30, 1998 and accepted November 6, 1998)
}

\begin{abstract}
As we know Taiwanese govemment restricts the import of fluid milk, but, Taiwan will be asked to open the market of lluid milk after becoming a member of WTO in near future. Thus, Taiwanese dairy industry may face the probiem of severe competitions. The objective of our serial studies is to make a preliminary research of whole Taiwanese dairy industry, including four sections of dairy farmers, dairy factories, dairy importers and consumcrs, then to develop a spatial price equilibrium model to evaluate changes in production, consumption, and trade of dairy products under altemative Taiwan and agrieultural trade policy regimes, finally to find out the future possible dairy products price in the world trade and its influence on Taiwanese dairy industry.

We can divide Taiwanese dairy industry into four sections as Figure 1 showed. In this paper, we only discuss the relation of raw milk demand and supply between dairy farmers and factories, developing a spatial equilibrium model for solving the equilibrium price for each factories and regional farmers. This study also examines the role of spatial equilibrium in the allocation of raw milk from farms to the thirty-three processing factories located in Taiwan. In the final part of this paper, we analyze the result and discuss the future problems which Taiwanese dairy industry may meet such as relocation and capacity reallocation possibilities of Tajwanese dairy factories under the situation of continuously increasing dernand as well as the pressure for liberalization of fluid milk trade.
\end{abstract}

\section{INTRODUCTION}

It is well known that for higher level income households, a bigger share of total expenditure on high quality food than is the case for lower level income households. Therefore, accompanying the increase of national income in Taiwan which being considered as a developed country, there is obviously increasing tendency in the dairy products demand (Table 1). However, the self sufficiency rate of dairy products in Taiwan is still small which is between $16.32 \%$ and $21.84 \%$ during last ten years. All of imported dairy products are manufactured dairy products, currently, and fluid milk is still restrictedly imported. Therefore, Taiwanese current raw milk materials are mostly used to produce fluid drinking milk which constitutes about half in fresh drinking milk, quarter in flavored and long life milk and quarter in fermented milk. Under these conditions, the liberalization of fluid milk trade will affect Taiwanese dairy industry seriously.

We would like to forecast future possible impact on Taiwanese dairy industry under the liberalized of fluid milk market according to the following stages. (1) We try to forecast the future situation of Taiwanese dairy industry assuming that there will be no 


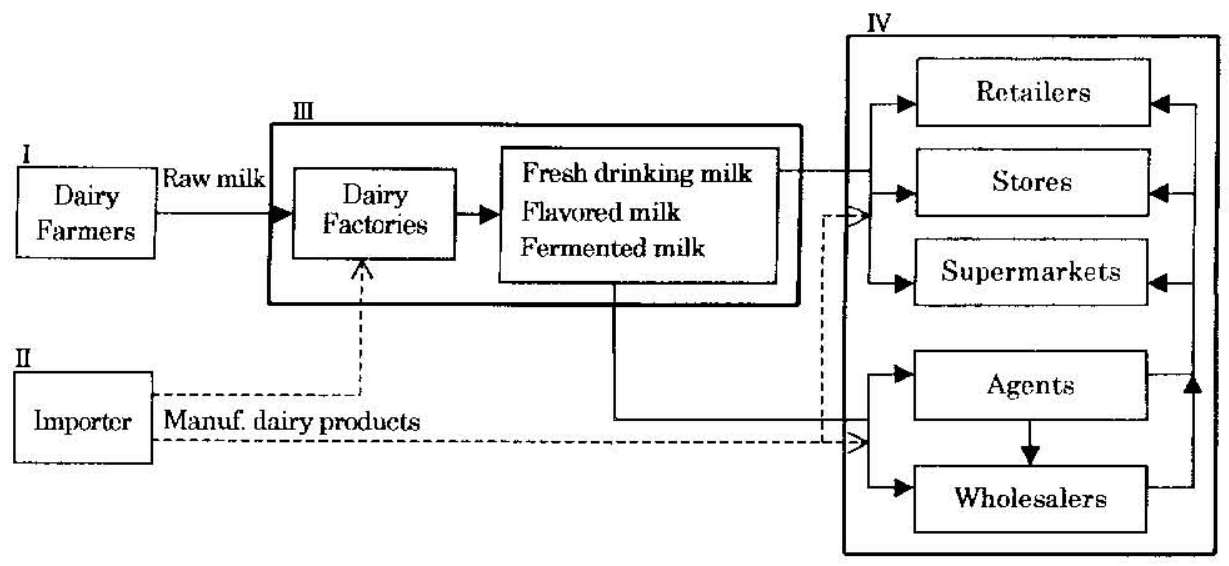

Fig. 1. Manufacturing and marketing routes of milk

Table 1. Milk consumption in Taiwan

\begin{tabular}{|c|c|c|c|c|c|c|}
\hline Year & $\begin{array}{l}\text { Population } \\
1000 \text { persons } \\
\text { (1) }\end{array}$ & $\begin{array}{l}\text { Domestic } \\
\text { raw milk } \\
\text { ton (2) }\end{array}$ & $\begin{array}{l}\text { Import dairy } \\
\text { products } \\
\text { ton (3) }\end{array}$ & $\begin{array}{l}\text { Total } \\
\text { consumption } \\
\operatorname{ton}(4)=(2)+(3)\end{array}$ & $\begin{array}{l}\text { Ave milk } \\
\text { consumplion } \\
\text { per person } \\
\mathrm{kg} .(5)=(4) /(1)\end{array}$ & $\begin{array}{l}\text { Self supporting } \\
\text { share in total } \\
\text { consumption } \\
\left.(6)=(2) /(4)^{*} 10\right)(1 \%\end{array}$ \\
\hline 1978 & 17102 & 44615 & 459513 & 504128 & 29.48 & 8.85 \\
\hline 1979 & 17375 & 44418 & 474460 & 518878 & 29.86 & 8.56 \\
\hline 1980 & 17619 & 47740 & 508810 & 556550 & 31.59 & 8.58 \\
\hline 1981 & 17953 & 50154 & 574313 & 624467 & 34.78 & 8.03 \\
\hline 1982 & 18270 & 55859 & 610373 & 666232 & 36.47 & 8.38 \\
\hline 1983 & 187333 & 58022 & 718947 & 776969 & 41.48 & 7.47 \\
\hline 1984 & 19013 & 66933 & 723822 & 790755 & 41.59 & 8.46 \\
\hline 1985 & 19258 & 87879 & 705101 & 792980 & 41,18 & 11.08 \\
\hline 1986 & $194 \% 5$ & 109723 & 827398 & 937121 & 48.17 & 11.71 \\
\hline 1987 & 19673 & $144: 390$ & 775678 & 920068 & 46.77 & 15.69 \\
\hline 1988 & 19904 & 173407 & 836895 & 1010302 & 50.76 & 17.16 \\
\hline 1989 & 20107 & 172421 & 883770 & 1056191 & 52.53 & 16.32 \\
\hline 1990 & 20353 & 203830 & 869057 & 1072887 & 52.71 & 19.00 \\
\hline 1991 & 20557 & 225656 & 1041907 & 1267563 & 61.66 & 17.80 \\
\hline 1992 & 20752 & 246281 & 1113848 & 1360129 & 65.54 & 18.11 \\
\hline 1993 & 20944 & 278476 & * 1180106 & 1458582 & 69.64 & 19.09 \\
\hline 1994 & 21126 & 289574 & 1186702 & 1476276 & 69.88 & 19.62 \\
\hline 1995 & 21304 & 317806 & 1245053 & 1562859 & 73.36 & 20.33 \\
\hline 1996 & 21520 & 315927 & 1150482 & 1466409 & 68.14 & 21.54 \\
\hline 1997 & 21743 & 330469 & $\mathrm{J1} 82416$ & 1512885 & 69.58 & 21.84 \\
\hline
\end{tabular}

Source: (1) Taiwan Statistical Data Book

(2) Agricultural Year Book 1997, P.D.A.F.

(3) Monthly Statistics of Exports and Imports, M.O.F.

Raw milk basis: fresh drinking milk $\times 1$, evaporated or condensed $\times 2.2$, powder or block $\times 9$, butter $\times 20$, cheese and curd $\times 9$

* The figures of this coloun from the year of 1993 to 1997 are estimated. 
structural changes in Taiwanese dairy industry. (2) Then we try to tind out all possible inconsistencies between the forecasted future situation and the practical structure of Taiwanese dairy industry in future. (3) Finally, we plan to make reasoning about the change of the situation of Taiwanese dairy industry in the future. In this paper, we utilize the raw milk trade flow between dairy farmers and dairy factories to estimate all of raw milk demand and supply in Taiwan. The method is to estimate supply and demand functions and to use those functions to develop the traditional single-product spatial equilibrium model assuming perfect competition. The usefulness of the model is demonstrated in the raw milk interregional market in Taiwan to pursue the equilibrium solution under perfect competition and to forecast the future raw milk supply, demand and prices. As a result, we discuss the possible development directions for both dairy farmers and factories and problems dairy industry may meet under liberalization pressure.

\section{TILORETICAL MODEL AND APPLICATION}

The spatial equilibrium model with intermediate products developed in this paper is static and involves partial equilibrium. It assumes perfect competition and homogeneous product. It also considers that there are no structural changes in supply and demand in the transition from a starting position to the new equilibrium, that is, prices and quantities are determined along supply and demand functions which remain unchanged in the basic model.

Applying econometric models, we can obtain both 14 producing counties' supply functions and 33 dairy factories' demand functions of raw milk as following analysis. Consequently, with linear supply and demand functions as well as unit transportation cost of raw milk, the objective function of the maximization problem to be solved for equilibrium solutions becomes a quadratic expression. In the presence of linear constraints, the problem can be solved by quadratic programming method. As a result, we can obtain the equilibrium solutions of raw milk supply, demand, trade flows and prices.

\section{Raw milk supply functions for 14 raw milk producing counties}

1. Distribution of dairy farms

Although Taiwanese self-sufficiency rate of dairy products is only around 20 percent, declines in the number of dairy farms but increases in milk production per farm causes the increases in total raw milk production in recent years. In this paper, we grouped 14 raw milk producing counties into 4 areas which are north, middle, south and east as shown in Table 2 according to the general division of Taiwan agricultural area. It is shown in Figure 2 that the distribution of Taiwanese dairy farms concentrates in the middle and south of Taiwan. Also it is clearly indicated in Table 2 that average scale per farm in south and east parts of Taiwan is larger than those in north and middle parts due to the higher density of population in north and middle and the cheaper land price in south and east.

2. The method of raw milk quota and price decision

From the year of 1983, Industrial Development Bureau (IDB) of Ministry of Economics Affairs began to decide the distribution of each factory's receiving raw milk, 


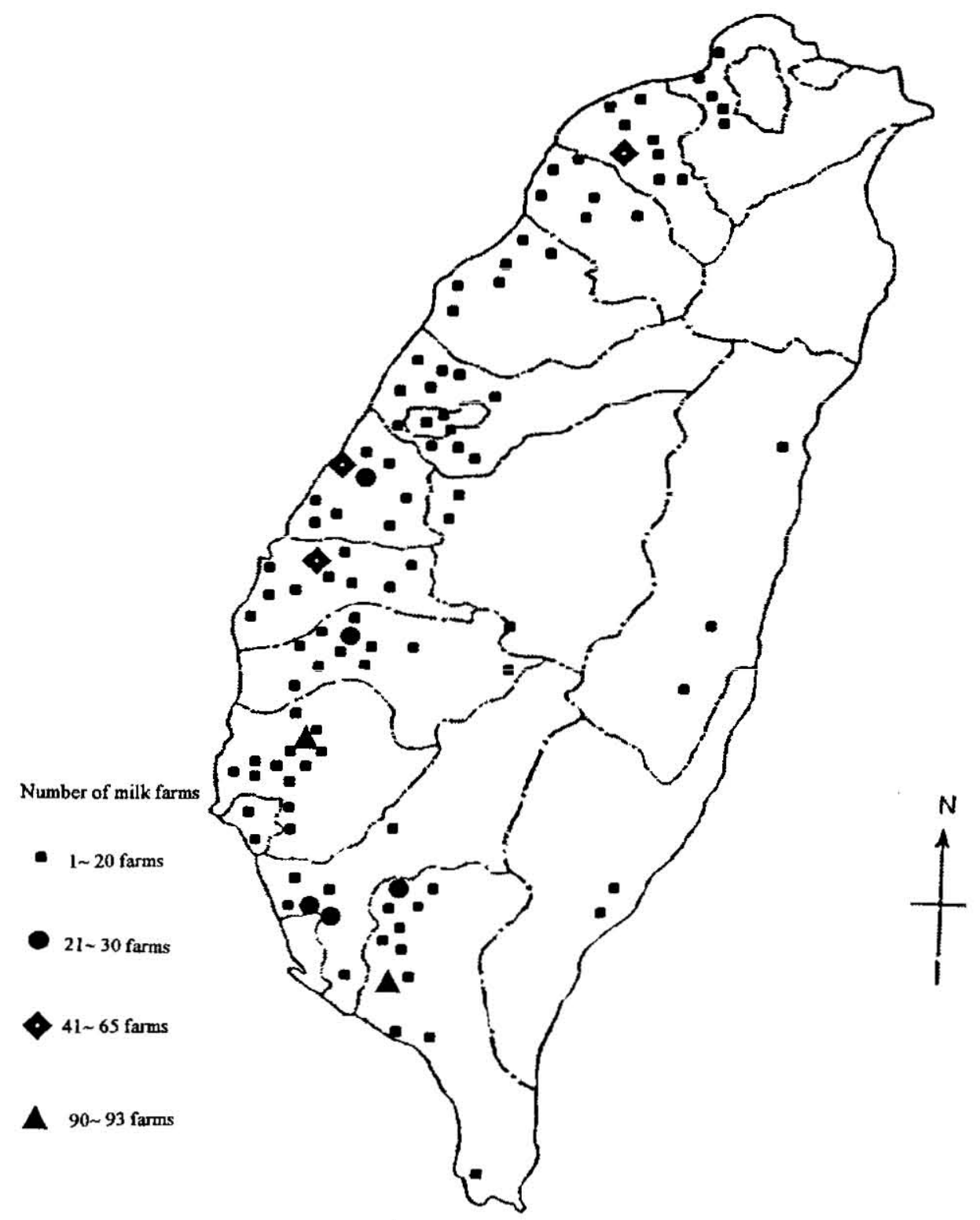

Source: Taiwan Provincial Department of Agriculture and Forestry

Fig. 2. Taiwanese milk farms' distributional map 
Table 2. 1996 Distribution and scale of Taiwanese dairy farms

\begin{tabular}{|c|c|c|c|c|c|c|}
\hline$m-n$ & 1. Taipei & 2. Taoyliarl & 3. Hsincku & 4. Miaoli & North $(1 \sim 4)$ & \\
\hline No. of farms & 15 & 69 & 20 & 58 & $162(16.82 \%)$ & \\
\hline Production & 5411 & 20141 & 7459 & 15596 & $48607(15.39 \%)$ & \\
\hline Ave ton/Farm & 361 & 292 & 373 & 269 & 300 & \\
\hline 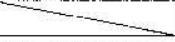 & 5. Taichurıg & 6. Changhwa & 7. Nantou & 8. Yunlin & 9. Chiayi & Middle $(5-9)$ \\
\hline No. of farms & 32 & 147 & 15 & 110 & 79 & $383(39.77 \%)$ \\
\hline Production & 7960 & 48480 & 3883 & 32342 & 21819 & $114484(36.24 \%)$ \\
\hline Ave.ton/Farm & 249 & 330 & 259 & 294 & 176 & 299 \\
\hline 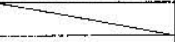 & 10. Tainan & 11. Kaoshiung & 12. Pintung & South $(10-12)$ & & \\
\hline No. of farms & 168 & 72 & 152 & $392(40.71 \%)$ & & \\
\hline Production & 72336 & 22474 & 48117 & $142927(45.25 \%)$ & & \\
\hline Ave.1on/Farm & 431 & 312 & 317 & 365 & & \\
\hline$m$ & 13. Taitung & 14. Hwalien & East $(13 \sim 14)$ & & & \\
\hline No. of farms & 12 & 14 & $26(2.70 \%)$ & & & \\
\hline Production & 4233 & 5625 & $9858(3.12 \%)$ & & & \\
\hline Ave.ton/Farm & 358 & 402 & 379 & & & \\
\hline
\end{tabular}

Unit of prodiction: Mt.

Source: Taiwan Provincial Department of Agriculture and Forestry, 1996 Sept. Survey and Statistics of Dairy Farms in Taiwan

and Taiwan Provincial Department of Agriculture and Forestry determined the area where each factory should be in charge to purchase raw milk according to IDB milk distribution standards of factories.

In another side of raw milk purchasing price of factories, it is not determined through direct market mechanism but decided indirectly through negotiation by some groups representatives such as dairy farmers, dairy factories, research institutions and government. Then factories can adjust the standard purchasing price to the actual raw milk purchasing price according to the raw milk fat rate, specific gravity, temperature, sediment and bacterium number. On the other hand, most of the factories pay all of the transportation cost between producing farms to factories.

\section{Supply functions}

The logarithmic linear equation for each raw milk producing area is specified as follows.

(1) $S Q^{A}=F\left(S Q_{t-1}^{A}, S P_{t}^{A}, D^{B}, u_{t}^{A}\right)$

Where $\mathrm{SQ}^{A}{ }_{\mathrm{L}}=$ total supply of raw milk in producing area, where $\mathrm{A}=\mathrm{N}$ : north of Taiwan, $\mathrm{A}=\mathrm{M}$ : middle of Taiwan, $\mathrm{A}=\mathrm{S}$ : south of Taiwan, $\mathrm{A}=\mathrm{E}$ : east of Taiwan, $\mathrm{t}=$ the annual observation, $\mathrm{SP}^{A}=\mathrm{P}_{0} / \mathrm{P}_{1}$ in producing area (Figure 3 ), $\mathrm{D}^{\mathrm{B}}=$ Dummy variables to measure regional (county) effects, when $A=N, B=1 \sim 3$; when $A=M, B=1 \sim 4$; when $A=S, B=1 \sim 2$; when $\mathrm{A}=\mathrm{E}, \mathrm{B}=1 ; \mathrm{u}^{\mathrm{A}}=$ disturbance term for area $\mathrm{A}$.

During the 1970s, the Nerlove partial adjustment model and the polynomial distributed lag model were often used in estimating milk supply response. Chen, Courtney, and Schmitz used a polynomial lag model to determine milk supply response in California with quarterly data. Hammond used both the Nerlove partial-adjustment model and a polynomial lag model with annual data to estimate milk supply functions for 
major U.S. producing arcas. In a 1978 study of the California dairy industry, Milligan rejected both lag specifications in favor of direct estimation of lagged profitability parameters. A bimonthly (six per year) series of data on profit margins was used (Milligan, 1978). In this paper, we combine and apply both the Nerlove partial-adjustment and Milligan model with amnual data to estimate milk supply function for Taiwanese raw milk producing areas.

In this study, annual observations for 1992-1997 are used to obtain single equation estimates of raw milk supply response for four areas in Taiwan, respectively. The availability of production cost data and the other relative data facilitate the specification of return over variable costs as the measure of profitability and a detailed analysis of the lagged response to raw milk production.

According to the Nerlove partial-adjustment theory (Nerlove, 1956), it is necessary to assume some relation between desired and actual production as equation ( 2 ) in order to make the operational hypotheses. (2) $Q_{1}-Q_{r-1}=\lambda\left(Q^{*},-Q_{1}\right)$ where $Q^{*}{ }_{1}=$ desired production, $Q_{1}=$ actual production, and $\lambda=$ a constant. (2) states that the charlge in actual production is proportional to the difference between desired and actual production.

Here, we also apply the profit maximizing theory to find a point on the production set with the maximal level of profits - this is a point where the vertical axis intercept of the associated isoprofit line is maximal. By inspection it can be seen that such an optimal point can be characterized by the tangency condition as follows (refer to Figure 3 ).

$$
\begin{array}{ll}
\pi=\mathrm{P}_{0} \mathrm{Y}-\mathrm{P}_{1} \mathrm{X} & \mathrm{d} \pi / \mathrm{dX}=\mathrm{P}_{0} \mathrm{~F}^{\prime}(\mathrm{X})-\mathrm{P}_{1}=0 \\
\mathrm{~F}^{\prime}(\mathrm{X})=\mathrm{P}_{1} / \mathrm{P}_{0} & \text { therefore } \mathrm{X}=\mathrm{G}\left(\mathrm{P}_{0} / \mathrm{P}_{1}\right)
\end{array}
$$

From this, we can realize that producing quantity is decided by both input and output price. Thcrefore, in our model of supply equations, we designate the selling price of raw milk over the producing cost as the predetermined variable of SP.

4. The result and analysis

Annual time series data for counties which belong to each area in Taiwan is studied

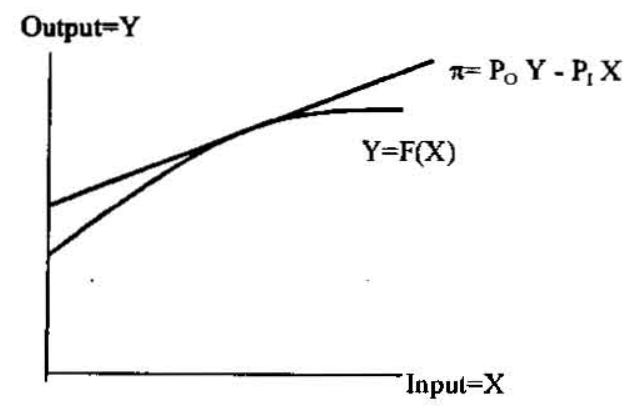

\author{
where $P_{1}$ : price of input \\ $P_{0}$ : price of output \\ $\pi$ : profit \\ $\pi=P_{0} Y-P_{I} X$ : isoprofit line \\ $\mathrm{Y}=\mathrm{F}(\mathrm{X})$ : production function
}

Profit maximization. The profit-maximizing amount of input occurs where the slope of the isoprofit line $\left(P_{1} / P_{O}\right)$ equals the slope of the production function.

Fig. 3. Conceptual representation of profit maximization 
Table 3. Raw milk trade flows from 14 supply regions to 33 factories and prices in 1996

Urit: ton and $\mathrm{NT} \$ / \mathrm{kg}$

\begin{tabular}{|c|c|c|c|c|c|c|c|c|c|c|c|c|c|c|c|c|c|}
\hline Area Fachistily & $\begin{array}{l}\mathbf{1}^{\mathbf{a}} \\
1^{11}\end{array}$ & $\begin{array}{l}2 \\
8 \\
\end{array}$ & $\begin{array}{c}3 \\
11 \\
\end{array}$ & $\begin{array}{l}4 \\
2 \\
\end{array}$ & $\begin{array}{c}5 \\
10 \\
\end{array}$ & $\begin{array}{l}\mathbf{6} \\
2 \\
\end{array}$ & $\begin{array}{l}7 \\
9\end{array}$ & $\begin{array}{l}8 \\
2 \\
\end{array}$ & $\begin{array}{l}9 \\
5 \\
\end{array}$ & $\begin{array}{c}10 \\
4\end{array}$ & $\begin{array}{c}11 \\
5\end{array}$ & $\begin{array}{c}12 \\
5 \\
\end{array}$ & $\begin{array}{c}13 \\
2 \\
\end{array}$ & $\begin{array}{c}14 \\
2 \\
-\end{array}$ & $\begin{array}{l}15 \\
11 \\
\end{array}$ & $\begin{array}{l}16 \\
13\end{array}$ & $\begin{array}{c}17 \\
5 \\
\end{array}$ \\
\hline $\begin{array}{l}\text { 1 Tainci } \\
2 \text { Tausuan } \\
3 \text { Hsinchu }\end{array}$ & $2,58 i\}$ & & $\therefore$ & & & $\begin{array}{r}1,062 \\
16,442 \\
6,998\end{array}$ & & $\begin{array}{r}931 \\
3,147\end{array}$ & & & & & 177 & 347 & & & \\
\hline $\begin{array}{l}4 \text { Miasli } \\
5 \text { Taichum }\end{array}$ & & & & 631 & & $\begin{array}{r}940 \\
1.404\end{array}$ & & & & 11,640 & 1,370 & $86 i$ & 370 & & & & \\
\hline 6 Changhwa & & & & 11,223 & & $\begin{array}{r}1.424 \\
697\end{array}$ & & & 22,405 & & & 778 & & & & & 5,153 \\
\hline 7 Nantou & & & & 1,184 & & & & & & & & & 1.497 & & & & \\
\hline $\begin{array}{l}8 \text { Viurilin } \\
9 \text { Chhayi }\end{array}$ & 24,040 & & & 7,135 & & & $\begin{array}{l}5,522 \\
9,06,8\end{array}$ & & & & & & 2,6533 & & & & \\
\hline 1) Tainan & 8,873 & & & & 26,394 & & 29,407 & & & & & & 5,735 & & & & \\
\hline $\begin{array}{l}11 \text { Kaohsiung } \\
\text { 12 Pingtemg }\end{array}$ & & 11,260 & 34,309 & & $\begin{array}{l}965 \\
542\end{array}$ & & 4.707 & & & & & & & & 1.247 & & \\
\hline $\begin{array}{l}13 \text { Taitung } \\
14 \text { Hwalien }\end{array}$ & & & & & 4,426 & & & & & & & & & & & 3,928 & \\
\hline Total & 35,494 & 11,260 & 34,909 & 20.173 & 32,376 & 27,503 & 48,594 & 8,078 & $22,650)$ & 11,540 & 1,370 & 859 & 10,432 & 347 & 1.547 & 3,928 & b,442 \\
\hline$\%$ & $11.3 \%$ & $3.6 \%$ & $11.1 \%$ & $6.4 \%$ & 10.396 & $8.8 \%$ & $15.5 \%$ & $13 \%$ & $7.2 \%$ & $3.7 \%$ & $4.4 \%$ & $0.3 \%$ & $3.3 \%$ & $0.1 \%$ & $0.5 \%$ & $1.3 \%$ & $2.1 \%$ \\
\hline
\end{tabular}

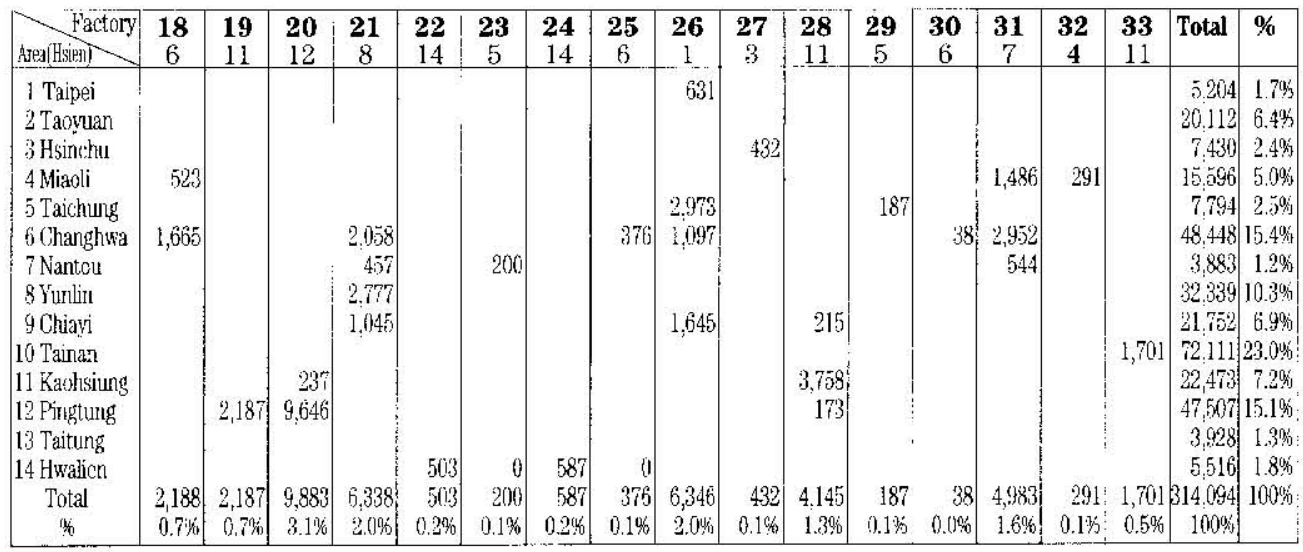

\begin{tabular}{lllllllllllllll}
\hline Supply Regions & 1 & 2 & 3 & 4 & 5 & 6 & 7 & 8 & 9 & 10 & 11 & 12 & 13 & 14
\end{tabular}

\begin{tabular}{lllllllllllllll} 
Pooled Price & 19.27 & 19.79 & 19.85 & 18.42 & 19.51 & 18.92 & 19.28 & 18.8 & 19.71 & 19.64 & 19.1 & 19 & 20.63 & 19.5 \\
\hline
\end{tabular}

\begin{tabular}{llllllllllllllllll}
\hline Factorics & 1 & 2 & 3 & 4 & 5 & 6 & 7 & 8 & 9 & 10 & 11 & 12 & 13 & 14 & 15 & 16 & 17
\end{tabular}

\begin{tabular}{llllllllllllllllll} 
Paid Price $^{-1}$ & 18.70 & 18.70 & 18.70 & 19.79 & 19.79 & 19.84 & 19.84 & 19.68 & 18.22 & 18.12 & 19.01 & 17.10 & 19.55 & 18.60 & 19.15 & 20.63 & 18.97 \\
\hline
\end{tabular}

\begin{tabular}{lllllllllllllllll}
\hline Factories & 18 & 19 & 20 & 21 & 22 & 33 & 24 & 25 & 26 & 27 & 28 & 29 & 30 & 31 & 32 & 33
\end{tabular}

\begin{tabular}{lllllllllllllllll} 
Paid Price $^{4}$ & 18.63 & 19.25 & 20.18 & 18.06 & 18.78 & 17.20 & 17.71 & 19.10 & 20.03 & 20.05 & 19.35 & 17.37 & 19.10 & 19.17 & 19.00 & 19.15 \\
\hline
\end{tabular}

Source: Taiwan Provincial Department of Agriculture and Forestry

a The number from 1 to 33 represents the factories, herc we do not include the name of factories (company) because of privacy.

n The number in this raw indicates the area which factory is located in, and same as the number represented in the column of Area.

c The number of area from 1 to 4 indicates the north of Taiwan.

The number of area from 5 to 9 indicates the middle of Taiwan.

The number of area from 10 to 12 indicates the south of 'Taiwan.

The number of area from 13 to 14 indicates the east of Taiwan.

a This price does inciude tranportation cost. 
Table 4. Raw milk supply response coefficient.s for 4 arcas of Taiwan, 1992-1997

Coefficients for Predetermined Variables

\begin{tabular}{|c|c|c|c|c|c|c|c|c|c|}
\hline $\begin{array}{l}\text { Dependent } \\
\text { Variable }\end{array}$ & Constant & $S Q_{1-1}$ & $\mathrm{SP}$ & DI & D2 & DS3 & D4 & $\mathrm{R}^{\prime 2}$ & $\begin{array}{l}\text { Price } \\
\text { Elasticity }\end{array}$ \\
\hline$S Q^{N}$ & $\begin{array}{l}2.6882 \\
{ }^{n}(3.27)^{* *}\end{array}$ & $\begin{array}{l}0.6591 \\
(6.73)^{* *}\end{array}$ & $\begin{array}{l}0.4951 \\
(3.02)^{* *}\end{array}$ & $\begin{array}{l}0.4471 \\
(3.70)^{* *}\end{array}$ & $\begin{array}{l}0.0838 \\
(2.42)^{*}\end{array}$ & $\begin{array}{l}0.4099 \\
(3.70)^{* *}\end{array}$ & - & 0.992 & 1.4524 \\
\hline$S Q^{N}:$ & $\begin{array}{l}3.8201 \\
(5.16)^{* * *}\end{array}$ & $\begin{array}{l}0.5619 \\
(6.61)^{* *}\end{array}$ & $\begin{array}{l}0.2401 \\
(1.84)\end{array}$ & $\begin{array}{l}0.8106 \\
(5.53)^{* *}\end{array}$ & $\begin{array}{l}-0.3039 \\
(-4.72)^{* *}\end{array}$ & $\begin{array}{l}0.6330 \\
(5.32)^{* *}\end{array}$ & $\begin{array}{l}0.4255 \\
(5.15)^{* *}\end{array}$ & 0.998 & 0.5481 \\
\hline$S Q:$ & $\begin{array}{l}2.2405 \\
(3.16)^{* *}\end{array}$ & $\begin{array}{l}0.7926 \\
(12.00)^{* *}\end{array}$ & $\begin{array}{l}0.2242 \\
(1.65)\end{array}$ & $\begin{array}{c}0.2509 \\
(-3.38)^{* *}\end{array}$ & $\begin{array}{l}-0.0569 \\
(-1.31)\end{array}$ & - & - & 0.995 & 1.0809 \\
\hline$S Q^{E_{L}}$ & $\begin{array}{l}4.3773 \\
(4.56)^{* *}\end{array}$ & $\begin{array}{l}0.4308 \\
(3.54)^{\text {*** }}\end{array}$ & $\begin{array}{l}0.6607 \\
(3.40)^{* * *}\end{array}$ & $\begin{array}{l}0.1844 \\
(3.58)^{* *}\end{array}$ & - & - & - & 0.975 & 1.1608 \\
\hline
\end{tabular}

"t-values are in parentheses

Double and single asterisks imply significance at the $1 \%$ and $5 \%$ levels, respectively.

Logarithric: values of variables (exclude dununy variables) are used for regression analyses.

Table 5. Raw milk supply equations of 14 regions

Unit: 1000 ton, $\mathrm{NT} \$ / \mathrm{kg}$.

\begin{tabular}{|c|c|c|c|c|}
\hline $\mathrm{Q} 1=$ & -2.354 & + & 0.392 & PI \\
\hline$Q 2=$ & -9.099 & $\div$ & 1.476 & $\mathrm{P} 2$ \\
\hline$Q 3-$ & -3.362 & + & 0.544 & $\mathrm{P} 3$ \\
\hline$Q 4=$ & -7.056 & + & 1.230 & P4 \\
\hline$Q 5=$ & 3.522 &.+ & 0.219 & $\mathrm{P} 5$ \\
\hline$Q 6=$ & 21.894 & + & 1.404 & $\mathrm{P} 6$ \\
\hline$Q 7=$ & 1.755 & + & 0.110 & $\mathrm{P7}$ \\
\hline Q8- & 14.614 & + & 0.941 & P8 \\
\hline$Q 9=$ & 9.830 & + & 0.605 & P9 \\
\hline$Q 10=$ & -5.834 & + & 3.969 & P10 \\
\hline$Q 11=$ & -1.818 & + & 1.269 & Pll \\
\hline $\mathrm{Q} 12=$ & -3.843 & + & 2.697 & P12 \\
\hline Q13= & -0.632 & + & 0.221 & P13 \\
\hline Q14= & -0.887 & + & 0.329 & P14 \\
\hline
\end{tabular}

Wc use the following equation to estimate supply

equations:

$$
\mathrm{Q}=(1-\mathrm{e}) \overline{\mathrm{Q}}+\mathrm{e}(\overline{\mathrm{Q}} / \overline{\mathrm{P}}) \mathrm{P}
$$

where $\mathrm{e}$ : price elasticity of supply

$\bar{Q}$ : supply quantity in 1996

$\overline{\mathrm{P}}$ : market price in 1996

by multiple regression analysis, which result for respective area is shown in Table 4 . The result shows the equation (1) in respective 4 areas contains the variables that explained at least 97 percent of raw milk supply variations during 1992-1997. In north area, the average effect of a one percent increase in price change has been a 1.45 percent increase in raw milk supply which is highest among 4 areas. In contrast, in middle area there has bcen a 0.55 percent increase which is lowest. Based on the data of raw milk supply price elasticity presented in Table 4 , as well as the regional price and quantity observations of 
1996 in Table 3, linear marginal cost functions for each region are specified in Table 5.

\section{Raw milk demand functions for 33 dairy factories}

1. Distributions of dairy factories

In Figure 4, showing the distribution of all 33 Taiwanese raw milk manufacturing factorics in 1996, it is obvious that most of factorics arc located in north and middle parts of Taiwan since milk consumption is also concentrated in those parts and this causes some transportation problems between raw milk producers and factories (Lin and Kawaguchi, 1998). Based on the data of Table 6, we can know that the three leading dairy companies account for more than 68 percent of total raw milk processing in Taiwan. We can reason that some small dairy factory will be sacrificed under future severer competitions if Taiwan dairy companies behave as high density oligopolists.

\section{Demand functions}

The logarithmic linear equation for raw milk factory is specified as follows.

(3) $\mathrm{QD}=\mathrm{F}(\mathrm{PD}, \mathrm{I}, \mathrm{D}, \mathrm{u})$

Where $\mathrm{QD}=$ total raw milk demand of factory; $\mathrm{PD}=$ price paid by factory; $\mathrm{I}=$ per capita personal annual income; $D_{\mathrm{N}}=$ Dummy variables to measure area (north, middle, south, and east) effects, when $\mathrm{N}=1 \sim 3 ; \mathrm{D}_{\mathrm{v}}=$ Dummy variables to measure year (year of $1996=1$, other years $=0$ ) effects, when $\mathrm{N}=4$; $\mathrm{u}=$ disturbance term.

The factory demand is the endogenous variable and factory paid price is the predetermined variable for the raw milk demand equation. Several other forces may also influence the position of factory demand curve for raw milk. Since raw milk demand for factory is derived from consumer demand for fluid milk products, the factors influencing consumer demands for milk products are undoubtedly reflected through the marketing system to affect factory's expectations about the quantity of each wholesale cut demanded at various wholesale prices. Primary among these factors are the level of consumer income and the size of the consuming population, which were introduced directly into the demand equation to estimate the influence of changes in these variables. Because Taiwan population and per capita personal income have been highly correlated $(\mathrm{r}=0.97)$, a per capita income variable was specified in the model to account for the effect of both income and population effects.

Table 6. Raw milk processing shares among top dairy comparies

\begin{tabular}{|l|l|l|l|l|ll|}
\hline Year & 1992 & 1993 & 1994 & 1995 & 1996 & 1997 \\
\hline $\begin{array}{l}\text { Number of dairy } \\
\text { company }\end{array}$ & 30 & 31 & 30 & 30 & 29 & 28 \\
$\begin{array}{l}\text { Total processing } \\
\text { quantity (100 ton) }\end{array}$ & 2417 & 2744 & 2853 & 3152 & 3141 & 3271 \\
Top 3's dairy & 1566 & 1754 & 1818 & 2087 & 2104 & 2233 \\
$\begin{array}{l}\text { company share } \\
\text { Top 10's dairy }\end{array}$ & $(64.79 \%)$ & $(63.92 \%)$ & $(63.72 \%)$ & $(66.21 \%)$ & $(66.99 \%)$ & $(68.27 \%)$ \\
company share & $(88.75 \%)$ & $(87.90 \%)$ & $(88.12 \%)$ & $(89.40 \%)$ & $(90.45 \%)$ & $(91.20 \%)$ \\
\hline
\end{tabular}

Sourcc: Taiwan Provincial Department of Agriculture and Forestry, 1992-1997 Survey and Statistics of Dairy Factories in Taiwan 


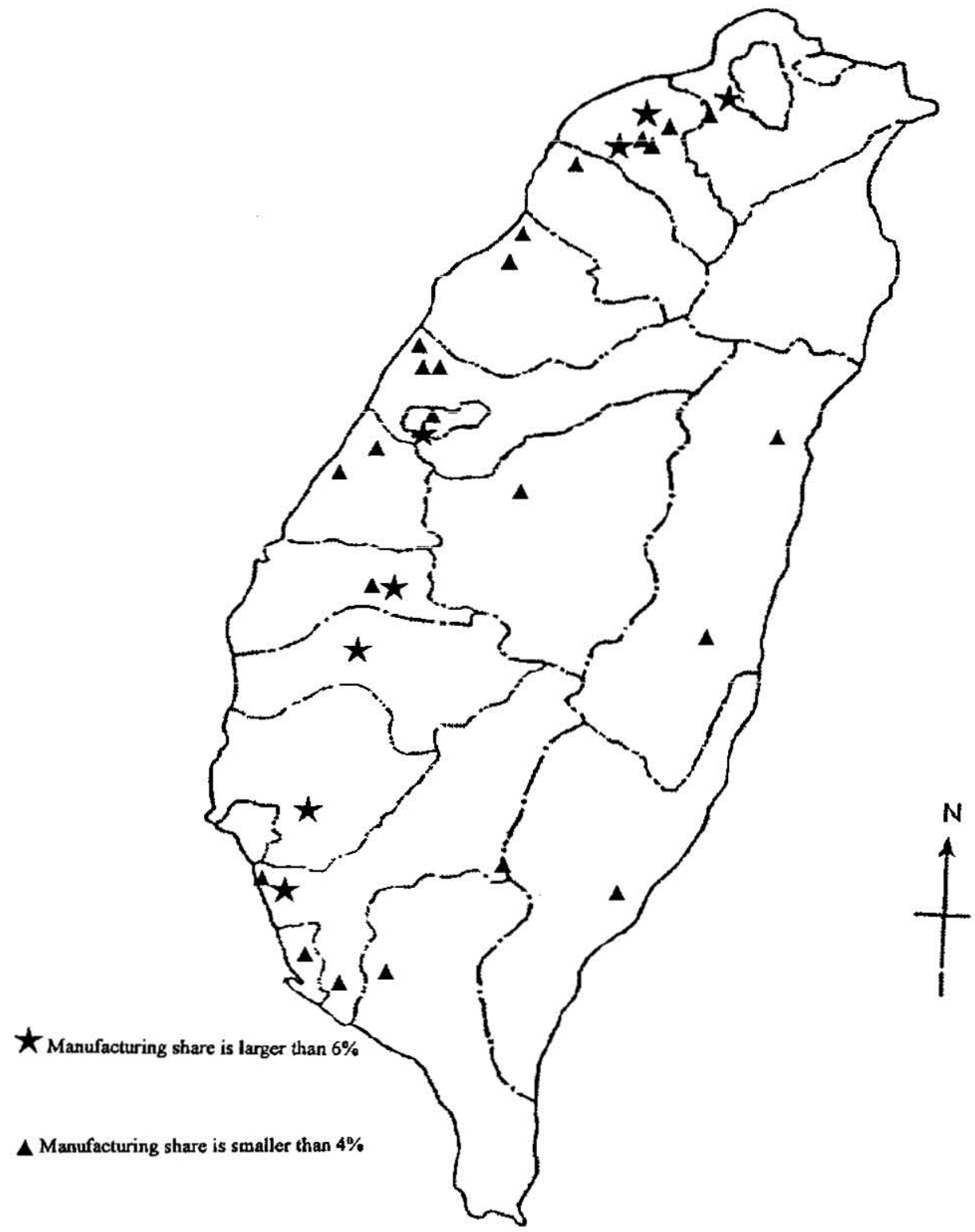

Source 1996: Taiwan Provincial Department of Agriculture and Forestry

Fig. 4. Taiwanese milk factories' distributional map 
Demand fluctuations among areas in raw milk marketing system are thought to occur and be affected by climates, geographical features and land use patterns. Consequently, dummy variables associated with each area were specified to account for area demand shifts due to otherwise unquantified variables in the demand equations. In addition, in 1996, the raw milk supply did not increase as usual because the mad cow disease of BSE (Bovine Spongiform Encephalopathy) occurred in Europe which led to prohibit the import of cow from Europe in Taiwan. Therefore, we use dummy variables to measure year (year of $1996=1$, other years $=0$ ) effects.

\section{The result and analysis}

Annual time series data covering four areas in Taiwan are studied by multiple regression analysis, which result is shown in Table 7 . The result shows the equation (3) contains the variables that explained approximately 99 percent of raw milk supply variations during 1992-1997. The average effect of one percent increase in price change has been a 0.71 percent reduction in raw milk demand among 33 factories. In another side, the average effect of 1 percent increase in income change has been a 1.15 percent increase in raw milk demand. Based upon the data of raw milk demand price elasticity and income elasticity indicated in Table 7, as well as the price paid by factories and observations in Table 3 , linear demand functions for each factories are specified in Table 8.

\section{Application of spatial price equilibrium (SPE) model}

Spatial equilibrium analysis is well known as a quantitative method to analyze the structure of interregional competition of various products. This new approach to the spatial pricing and allocation problem began at development of activity analysis model by Koopmans (1949) and Dantzing (1951). Stephen Enke (1951) formulated the problem concerning competitive equilibrium among spatially separated markets and suggested how a solution in the case of linear market functions might be obtained by electric analogue. Samuelson (1952) showed how this purely descriptive problem in non-normative economics can be cast mathematically into a maximum problem and relates the Enke specification to a standard problem in linear programming, the so-called Koopmans-Hitchcock minimum-transport-cost problem. Operational effectiveness of the mathematical programming approach for the solution of market equilibrium over space was significantly enhanced by the Takayama and Judge (1964) quadratic programming formulation of spatial price and allocation models, and Takayama and Judge (1971)

Table 7. Raw milk demand response coefficients for Taiwanese dairy factories, 1992-1997

Coefficients for Predetermined Variables

\begin{tabular}{lllllllll}
\hline $\begin{array}{l}\text { Dependent } \\
\text { Variable }\end{array}$ & Constant & $\begin{array}{l}\text { Price } \\
\text { Elasticity }\end{array}$ & $\begin{array}{l}\text { Income } \\
\text { Elasticity }\end{array}$ & D1 & D2 & D3 & D4 & $\mathrm{R}^{2}$ \\
\hline $\mathrm{QD}_{\mathrm{r}}$ & 2.6882 & -0.714 & 1.148 & -0.019 & -0.339 & -3.152 & -0.082 & 0.999 \\
& $(-0.28)^{\mathrm{*}}$ & $(-3.57)^{* *}$ & $(6.33)^{* *}$ & $(-0.62)$ & $(-10.85)^{* *}$ & $(-99.97)^{* *}$ & $(-2.16)^{*}$ & \\
\hline
\end{tabular}

t-values are in parentheses

Double and single asterisks imply significance at the $1 \%$ and $5 \%$ levels, respectively.

I.ogarithmic: valıes of variables (cxclude dummy variables) are used for regression analyses. 
Table 8. Raw milk demand functions of '33 dairy factories in1996

Unit: 1000 ton, NTS/kg.

\begin{tabular}{|c|c|c|c|c|c|c|c|c|c|}
\hline D1 & $=$ & 60.8367 & -1.3552 & DP 1 & + & 0.0001496 & (I I & - & $\left.I_{n}\right)$ \\
\hline D2 & $=$ & 19.2996 & -0.4299 & DP2 & + & 0.0000475 & (I 2 & - & $\left.1_{6}\right)$ \\
\hline D3 & $=$ & 59.8340 & -1.3329 & DP3 & + & 0.0001471 & (I 3 & - & If) \\
\hline D4 & $=$ & 34.5765 & -0.7278 & DP 4 & + & 0.0000850 & (I 4 & - & $\left.I_{0}\right)$ \\
\hline D5 & $=$ & $5 \overline{5} .4925$ & -1.1681 & DP 5 & + & 0.0001364 & (I 5 & - & $\left.I_{i n}\right)$ \\
\hline D6 & $=$ & 47.1401 & -0.9898 & $D P 6$ & + & 0.0001159 & (I 6 & - & $\left.I_{0}\right)$ \\
\hline D7 & $=$ & 83.4615 & -1.7524 & Г)Р 7 & + & 0.0002052 & (I 7 & - & $\left.\mathrm{L}_{0}\right)$ \\
\hline D8 & $=$ & 6.9897 & -0.1480 & DP 8 & + & $0.000017^{2} 2$ & (I 8 & - & $\left.I_{i}\right)$ \\
\hline D9 & $=$ & 38.8307 & -0.8734 & DP 9 & + & 0.0000955 & (I 9 & - & $\left.I_{i}\right)$ \\
\hline I)10 & $=$ & 19.9510 & -0.4587 & DP 10 & + & 0,0000491 & (I 10 & - & 10) \\
\hline I)11 & $=$ & 2.3482 & -0.0515 & DP 11 & + & 0.0000058 & (I 11 & & $\left.I_{0}\right)$ \\
\hline D12 & $=$ & 1.4723 & -0.0359 & DP 12 & + & 0.0000036 & (I 12 & - & $\left.I_{0}\right)$ \\
\hline $\mathrm{DH}$ & $=$ & 17.8804 & -0.3810 & DP 13 & + & 0.0000440 & (I 13 & - & $\left.I_{0}\right)$ \\
\hline D14 & $=$ & 0.5948 & -0.0133 & DP 14 & + & 0.0000015 & (I 14 & - & $\left.I_{i}\right)$ \\
\hline D15 & $=$ & 2.6516 & -0.0577 & DP 15 & + & 0.0000065 & (I 15 & - & $\left.I_{0}\right)$ \\
\hline D16 & $=$ & 6.7326 & -0.1359 & DP 16 & + & 0.0000166 & (I 16 & - & $\left.\mathrm{I}_{0}\right)$ \\
\hline D17 & $=$ & 11.0416 & -0.2431 & DP 17 & + & 0.0000271 & (I 17 & - & $\left.\mathrm{I}_{0}\right)$ \\
\hline D18 & $=$ & 3.7502 & -0.0839 & DP 18 & + & 0.0000092 & (I 18 & - & $\left.I_{0}\right)$ \\
\hline D19 & $=$ & 3.7485 & -0.0811 & DP 19 & + & 0.0000092 & (I 19 & - & I.) \\
\hline D20 & $=$ & 16.9395 & -0.3497 & DP 20 & + & 0.0000417 & (I 20 & - & $\left.\mathrm{I}_{0}\right)$ \\
\hline 1221 & $=$ & 10.8633 & -0.2506 & DP 21 & + & 0.0000267 & (I 21 & - & $\left.I_{w}\right)$ \\
\hline 1222 & $=$ & 0.8621 & -0.0191 & DP22 & + & 0.0000021 & (I 22 & - & $\left.I_{3}\right)$ \\
\hline D23 & $=$ & 0.3428 & -0.0083 & DP 23 & $\perp$ & 0.0000008 & (I 23 & - & $\left.\mathrm{I}_{i}\right)$ \\
\hline D24 & $=$ & 1.0061 & -0.02337 & $\mathrm{DP} 24$ & + & 0.0000025 & (I 24 & - & $\left.I_{1}\right)$ \\
\hline D25 & $=$ & 0.6445 & -0.0141 & DP25 & + & 0.0000016 & (I 25 & - & $\left.\mathbf{I}_{1}\right)$ \\
\hline D26 & $=$ & 10.8770 & -0.2262 & DP26 & + & 0.0000267 & (I 26 & - & $\left.I_{0}\right)$ \\
\hline $\mathrm{D}^{\prime} 27$ & $=$ & 0.7404 & -0.0154 & DP 27 & + & 0.0000018 & (I 27 & - & $\left.\mathrm{I}_{i}\right)$ \\
\hline D28 & $=$ & 7.1045 & -0.1529 & DP 28 & + & 0.0000175 & $(128$ & - & $\left.I_{41}\right)$ \\
\hline D29 & $=$ & 0.3205 & -0.0077 & DP29 & + & 0.0000008 & (I 29 & - & $\left.I_{0}\right)$ \\
\hline D30 & $=$ & 0.0651 & -0.0014 & IPP 30 & + & 0.0000002 & (I 30 & - & $\left.\mathrm{I}_{0}\right)$ \\
\hline D31 & $=$ & 8.5409 & -0.1856 & DP 31 & + & 0.0000210 & (I 31 & - & $\left.\mathrm{I}_{0}\right)$ \\
\hline D32 & $=$ & 0.4988 & -0.0109 & DP 32 & + & 0.0000012 & (I 32 & - & $\left.I_{0}\right)$ \\
\hline D33 & $=$ & 2.9155 & -0.0634 & DP 33 & + & 0.0000072 & (I 33 & - & $\left.I_{i}\right)$ \\
\hline
\end{tabular}

We use the following equation to estimate demand equations:

$\left.\mathrm{D}=\left[\mathrm{D}(1-\beta)+\gamma\left(\mathrm{D}_{i} / \mathrm{I}_{\mathrm{u}}\right)\left(\mathrm{I}-\mathrm{I}_{\mathrm{i}}\right)\right]+\beta(\mathrm{D}) / \mathrm{P}_{\mathrm{i}}\right) \mathrm{P}$

where $\beta$ : price elasticity, $\gamma$ : income elasiticity

$\mathrm{D}_{1}$ : demand in $1996, \mathrm{P}_{2}$ : price in 1996

$\mathrm{I}_{\mathrm{N}}$ : income in 1996

presented two versions of the spatial pricing and allocation models: a perfectly competitive market model and a monopoly model. Hashimoto (1985) presented a SPE model that describes behavior of an oligopolistic market, characterized as a Nash non-cooperative game.

Recently the SPE model has been widely adopted either in theoretical advances or in empirical applications. Several approaches have been taken to study the implications of trade liberalization and the formation of regional blocs on the agricultural sector. The approach taken in this paper is based on the mathematical programming models 
developed by Samuelson (1952) and Takayama and Judge (1964, 1971), to analyze the allocation of raw milk under perfectly competitive market.

By developing the economic theory and explaining the economic reason, the equilibrium condition of the problem can be derived. Making use of the estimated linear regional demand and marginal cost functions, the equilibrium condition of interconnected competitive markets is either expressed as optimal condition of a Quadratic Programming Problem (QPP)or expressed as a Linear Complementary Problem (LCP). Given this QPP or LCP formulation, a computational algorithm is specified to obtain directly and efficiently the competitive equilibrium solution for regional prices and interregional flows.

\section{Model Description}

It is assumed there are $\mathrm{n}$ supply areas and each of them produces one given commodity. And there are $m$ regions (factories) that demand this commodity. The commodity is assumed to be traded frecly from any supply area to any consuming region; moreover, traded freely by transmission dealers among any consuming regions.

The notation listed below will be used in this paper.

$\mathrm{Y}_{\mathrm{j}} \quad=$ raw milk demand in factory $\mathrm{j}(\mathrm{j}=1,2, \ldots \ldots, \mathrm{m}), \mathrm{m}=33$

$\mathrm{X}_{\mathrm{i}} \quad=$ raw milk supply in producing county $\mathrm{i}(\mathrm{i}=1,2, \ldots \ldots, \mathrm{n}), \mathrm{n}=14$

$\mathrm{X}_{\mathrm{i}} \quad=$ the shipped amount from supply county $i$ to factory $\mathrm{j}$.

$\mathrm{PD}_{\mathrm{j}} \quad=$ price paid in factory $\mathrm{j}$.

$\mathrm{MC}_{\mathrm{i}} \quad=$ marginal cost in supply county $\mathrm{i}$.

$\mathrm{FC}_{\mathrm{i}} \quad$ = fixed cost portion of total cost in supply county $\mathrm{i}$.

$\mathrm{VC}_{\mathrm{1}}=$ variable cost portion of total cost in supply county $\mathrm{i}$.

$\mathrm{MR}_{\mathrm{i}} \quad=$ marginal revenue in supply county $\mathrm{i}$.

NSP = net social payoffs.

$\alpha_{\mathrm{j}} \quad=$ intercept value of the inverse linear demand function in factory $\mathrm{j}$

$\beta_{1} \quad=$ slope coefficient of the inverse linear demand function in factory $\mathrm{j}$

$\gamma_{i} \quad=$ intercept value of the linear marginal production cost function in supply area i

$\eta_{1} \quad=$ slope coefficient of the linear marginal production cost function in supply area i

$\mathrm{t}_{\mathrm{ij}}=$ unit transportation cost from supply area $\mathrm{i}$ to factory $\mathrm{j}$.

$\mathrm{PD}_{\mathrm{j}} \quad=\alpha_{\mathrm{j}}-\beta_{\mathrm{j}} \mathrm{Y}_{\mathrm{j}}$ inverse linear demand function in factory $\mathrm{j}$

$\mathrm{MC}_{1}=\gamma \mathrm{i}+\delta_{\mathrm{i}} \mathrm{X}_{\mathrm{i}}$ linear marginal production cost function in supply area $\mathrm{i}$

The model is specified as follows. Here we use quantity formulation, in which the decision variables are quantities, though we can alternatively use equivalent price formulation, in which the decision variables are prices.

Maximize

$\mathrm{NSP}=\sum_{j}\left\{\left\{\alpha_{i}-\beta Y_{i}\right\} d Y_{j}-\sum_{i}\left[\left\{\gamma_{i}+\delta_{i} X_{i}\right\} d X_{i}+F C_{i}\right]-\sum_{j} \sum_{j} t_{i j} X_{i j}\right.$

subject to $\sum_{i} X_{i j} \geq Y j$ for all $j, X_{i} \geq \sum_{j} X_{i j}$ for all $i$, and all variables are non-negative.

Lagrangean of this maximization problem is specified as follows.

$$
\operatorname{Ln}=\mathrm{NSP}+\sum_{j} \mathrm{P}_{j}\left(\sum_{i} \mathrm{X}_{i j}-\mathrm{Y}_{j}\right)+\sum_{i} \varphi_{i}\left(\mathrm{X}_{\mathrm{i}}-\sum_{j} \mathrm{X}_{i j}\right)
$$


where $P_{j}$ and $\varphi_{i}$ are the corresponding nonnegative Lagrangean multipliers.

The Kuhn-Tucker conditions associated with this problem are both necessary and sufficient conditions for an optimal solution, under the assumptions of differentiability and concavity of the objective function, and in the presence of linear constraints. The Kuhn-Tucker conditions are specified as follows.
(4.a) $\frac{\partial \mathrm{I}_{n}}{\partial \mathrm{X}_{\mathrm{ij}}}=\mathrm{P}_{\mathrm{j}}-\mathrm{t}_{\mathrm{ij}}-\varphi_{\mathrm{l}} \leq 0$
$; \mathrm{X}_{\mathrm{ij}} \geq 0 \quad ; \frac{\partial \mathrm{L}_{4 \mathrm{i}}}{\partial \mathrm{X}_{\mathrm{ij}}} \mathrm{X}_{\mathrm{ij}}=0$
for all $i$ and $j$,
(4.b) $\frac{\partial \mathrm{L}_{m}}{\partial \mathrm{Y}_{\mathrm{j}}}=\alpha_{\mathrm{j}}-\beta_{\mathrm{j}} \mathrm{Y}_{\mathrm{j}}-\mathrm{P}_{\mathrm{j}} \leq 0 \quad ; \mathrm{Y}_{\mathrm{j}} \geq 0 \quad ; \frac{\partial \mathrm{L}_{\mathrm{n}}}{\partial \mathrm{Y}_{\mathrm{j}}} \mathrm{Y}_{\mathrm{j}}=0$
for all $\mathrm{j}$,
(4.c) $\frac{\partial \mathrm{L}_{41}}{\partial \mathrm{X}_{\mathrm{i}}}=-\left(\gamma_{\mathrm{i}}+\delta_{\mathrm{i}} \mathrm{X}_{\mathrm{i}}\right)+\varphi_{\mathrm{i}} \leq 0 ; \mathrm{X}_{\mathrm{i}} \geq 0 \quad ; \frac{\partial \mathrm{L}_{n}}{\partial \mathrm{X}_{\mathrm{i}}} \mathrm{X}_{\mathrm{i}}=0$
for all i,
(4.d) $\frac{\partial L_{n}}{\partial P_{j}}=\sum_{i} X_{i j}-Y_{j} \geq 0$
$; \mathrm{P}_{\mathrm{j}} \geq 0 \quad ; \frac{\partial \mathrm{L}_{n}}{\partial \mathrm{P}_{\mathrm{j}}} \mathrm{P}_{\mathrm{j}}=0$
for all $\mathrm{j}$,
(4.e) $\frac{\partial \mathrm{L}_{m}}{\partial \varphi_{\mathrm{i}}}=\mathrm{X}_{\mathrm{i}}-\sum_{\mathrm{j}} \mathrm{X}_{\mathrm{ij}} \geq 0$
$; \varphi_{1} \geq 0 \quad ; \frac{\partial \mathrm{L}_{\hbar_{1}}}{\partial \varphi_{\mathrm{i}}} \varphi_{\mathrm{i}}=0$
for all i,

The Kuhn-Tucker conditions (4) imply the following corresponding statements (5):

$$
\begin{array}{lll}
\text { (5.a) } \mathrm{X}_{\mathrm{ij}}>0 \Rightarrow \mathrm{t}_{\mathrm{ij}}=\mathrm{P}_{\mathrm{j}}-\varphi_{\mathrm{i}} & , \frac{\partial \mathrm{L}_{\mathrm{il}}}{\partial \mathrm{X}_{\mathrm{ij}}}<0 \Rightarrow \mathrm{X}_{\mathrm{ij}}=0 \\
\text { (5.b) } \mathrm{Y}_{\mathrm{j}}>0 \Rightarrow \mathrm{P}_{\mathrm{j}}=\alpha_{\mathrm{j}}-\beta_{\mathrm{j}} \mathrm{Y}_{\mathrm{j}} & , \frac{\partial \mathrm{L}_{\mathrm{i}}}{\partial \mathrm{Y}_{\mathrm{j}}}<0 \Rightarrow \mathrm{Y}_{\mathrm{j}}=0 \\
\text { (5.c) } \mathrm{X}_{\mathrm{i}}>0 \Rightarrow \varphi_{\mathrm{j}}=\gamma_{\mathrm{i}}+\delta_{\mathrm{i}} \mathrm{X}_{\mathrm{i}} & , \frac{\partial \mathrm{L}_{m}}{\partial \mathrm{X}_{\mathrm{j}}}<0 \Rightarrow \mathrm{X}_{\mathrm{i}}=0 \\
\text { (5.d) } \mathrm{P}_{\mathrm{j}}>0 \Rightarrow \sum_{\mathrm{i}} \mathrm{X}_{\mathrm{ij}}=\mathrm{Y}_{\mathrm{j}} & , \frac{\partial \mathrm{L}_{n}}{\partial \mathrm{P}_{\mathrm{j}}}>0 \Rightarrow \mathrm{P}_{\mathrm{j}}=0 \\
\text { (5.e) } \varphi_{\mathrm{i}}>0 \Rightarrow \mathrm{X}_{\mathrm{i}}=\sum_{\mathrm{j}} \mathrm{X}_{\mathrm{ij}} & , \frac{\partial \mathrm{L}_{n}}{\partial \varphi_{\mathrm{i}}}>0 \Rightarrow \varphi_{\mathrm{i}}=0
\end{array}
$$

The Lagrangean multipliers are interpreted as shadow prices in competitive equilibrium. Namely $\varphi_{i}$ is interpreted as producer price in supply region $i$, and $P_{j}$ is interpreted as market price in factory j. Statement (4.a) and (5.a) indicate that the price difference between supply and demand regions (factories) is less than or equal to the unit transportation cost. Whenever trade takes place, the price difference is exactly equal to the unit transportation cost. Statement (4.b) and (5.b) imply that if there is any demand in region $\mathrm{j}$, the market price equals the demand price in factory j. Statement (4.c) and (5.c) indicate that the producer price is equal to the marginal cost, whenever the 
Table 9. Tableau of Kuhn-Tucker conditions

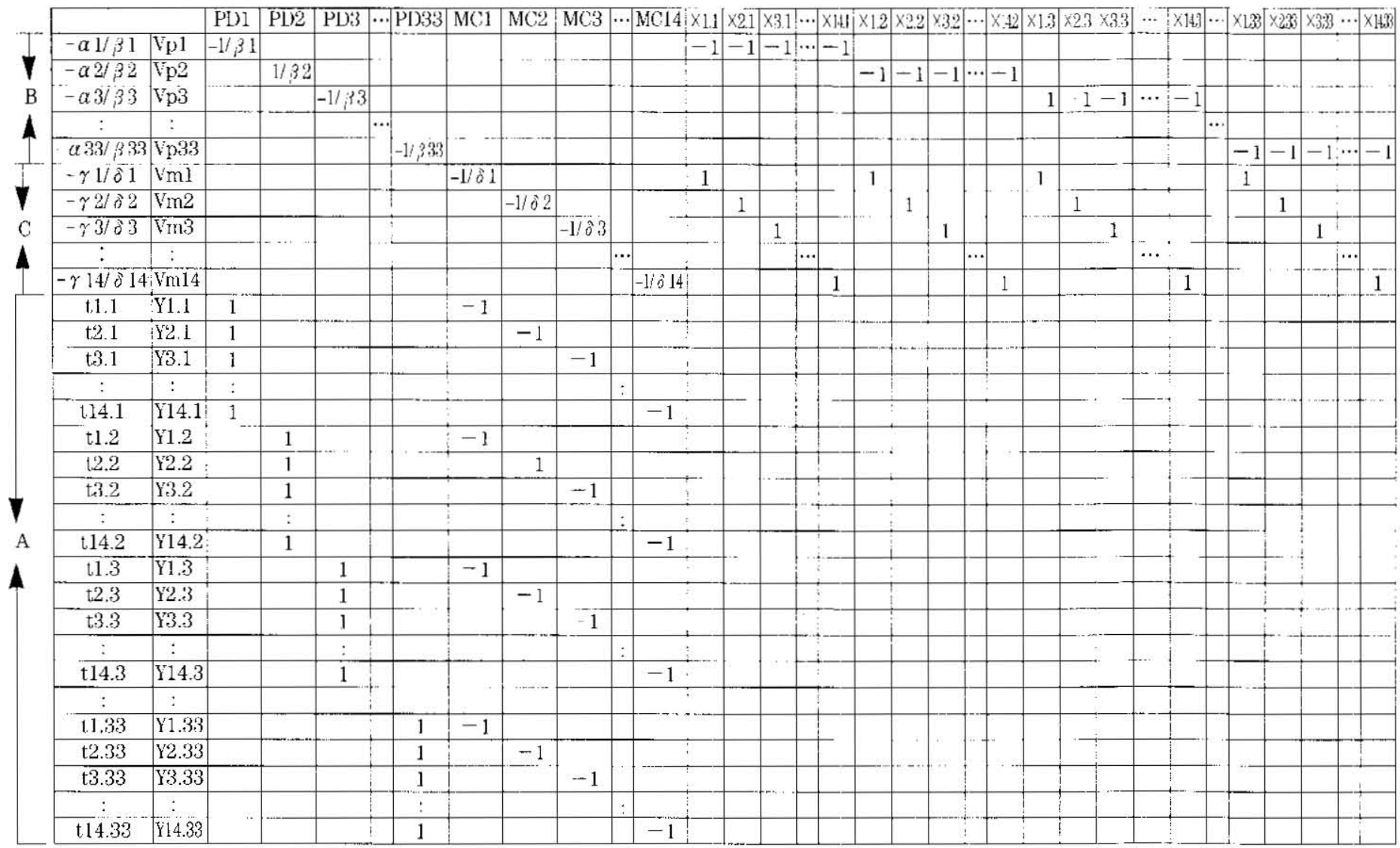

Part A corresponds to formula (4.a), part B corresponds to formila (4.d), and part (Ceorresponds to formula (4.e).

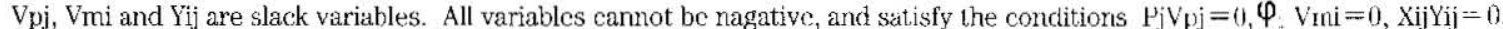

To clearly present, PDj instead of $\mathrm{Pj}$, and $\mathrm{MCi}$ instead $\varphi_{\mathrm{i}}$. 
production is positive.

Lastly, the remaining statements (4.d), (5.d) and (4.e), (5.e) reproduce the linear constraints of the optimization problem, implying the market clearing condition. In each region, production has to be greater than or equal to the domestic use plus exports to other regions (4.e), and consumption has to be less than or equal to domestic production plus imports from other regions (4.d). When the Lagrange multipliers (shadow prices) are positive, the conditions above hold with equality. On the other hand, if markets do not, clear, then the shadow prices are equal to zero.

All these statements taken together characterize an equilibrium solution for the traditional spatial equilibrium problem in perfectly competitive market. The Kuhn-Tucker conditions in the case of Tawanese raw milk market is formulated as in Table 9. In Table 9, the equality $P_{j}=\alpha_{j}-\beta_{j} Y_{j}$ and $\varphi_{i}=\gamma_{i}+\delta_{i} X_{i}$ are used to omit the variables $Y_{j}$ and $X_{i}$, assuming $Y_{j}$ and $X$ are both positive in practice. The optimal solution is obtained by Quadratic Programming Method.

\section{RESULT AND DISCUSSION}

According to above quantitative method, we can solve perfectly competitive spatial equilibrium problem by utilizing estimated supply and demand functions as weli as unit transportation cost of raw milk (Table 10). The result (Table 11) includes raw milk supply in each supply county, demand in each factory, trade flows, and prices in producing counties and factories. As long as trade takes place between producing county $i$ and factory $j$, the difference between the price in factory $j$ and the marginal production cost in county $i$ is equal to the transportation cost. Otherwise, no trade occurs when price difference is smaller than transportation cost. This kind of price relation is the feature of perfectly competitive spatial equilibrium.

We also forecast the future situation of raw milk market in twenty years presented in Table 12 15 based on income increase and under the assumption of unchangeable demand and supply structure of raw milk. The average income increasing rate of last twenty years calculated is around five percent per year. Surely this rate would not be stable at five percent every year in real world, but to the objective of the study, it dose not matter to precisely forecast future situation. Therefore, we assume that income increases at five percent each year in twenty years, then raw milk supply and demand will increase as well as those prices will rise every year. Under this condition, what kind of problems dairy industry may face to, and how to solve them are future important issues of concern.

First, to take the example of factory's side, as above mentioned, we consider some factories, which raw milk demand increases even more than twice during twenty years, may have to purchase machines or enlarge facilities. On the other hand, some small factories may not compete with other big factories under the future more difficult environment. In fact, some small factories which share of total raw milk processing is under one percent shown in Table 16 had met the problem of shutting down or seriously decreasing on raw milk demand during past six years. On the other side of dairy farmers, if the trend is toward as the forecast of raw inilk supply increase and price rise, farmers should consider some problems such as improvement, of farm management and feeding technology and so on. Thus, production supply structure of raw milk may vary in some 
Table 10. Unit raw milk transportation cost in 1996

Lnit: NT\$/ton

\begin{tabular}{|c|c|c|c|c|c|c|c|c|c|c|c|c|c|c|c|c|c|}
\hline Fat tory & $1^{\prime \prime}$ & 2 & 3 & 4 & 5 & 6 & 7 & 8 & 9 & 10 & 11 & 12 & 13 & 14 & 15 & 16 & 17 \\
\hline I l'aipei & 400 & 1200 & 1.400 & $4(0 i)$ & 1400 & 400 & 1200 & 400 & 1000 & 900 & 1000 & 1000 & 400 & $400^{\circ}$ & 1400 & $1400^{\circ}$ & 1000 \\
\hline 2 Taovuan & 400 & 1000 & 1400 & 400 & 1200 & 400 & 1200 & 400 & 900 & 650 & 900 & 900 & 400 & 400 & 1400 & 1400 & 900 \\
\hline 3 Hsinchu & $650^{\circ}$ & 900 & 1200 & 650 & 1200 & 650 & 1000 & 650 & 65()$^{!}$ & 400 & 6.50 & 650 & 650 & $650 \mathrm{j}$ & 1200 & 1400 & 650 \\
\hline 4 Miaoli & 900 & 900 & 1200 & 650 & 1000 & 630 & 900 & 650 & 650 & 400 & 650 & 650): & 650 & 650 & 1200 & 1400 & 650 \\
\hline 5 Taichung & 1000 & 650 & 1000 & 900 & 900 & 900 & 650 & 900 & $4(x)$ & 650 & 400 & 400 & 900 & 900 & 1000 & 1400 & 400 \\
\hline 6 Changhwa & 1000 & 400 & 1000 & 900 & $9(00)$ & 900 & 650 & 900 & 400 & 650 & 400 & 400 & 900 & 900 & 1000 & 1400 & 400 \\
\hline 7 Nantou & 1000 & 400 & 1000 & 1000 & 900 & 1000 & 650 & 1000 & $650 ;$ & 900 & 650 & 650 & $1000 \mid$ & 1000 & 1000 & 1400 & 650 \\
\hline $8 \mathrm{Yl}_{1}$ & 1200 & 400 & 900 & 1000 & 650 & 1000 & 400 & 1000 & 650 & 900 & 650 & 650 & 1000 & $1000^{\circ}$ & $9(10$ & 1400 & 650 \\
\hline $9 \mathrm{C}$ & 1200 & 400 & 650 & 1200 & 6500 & 1200 & $400^{\circ}$ & 1200 & 650 & $900^{\prime}$ & 650 & 650 & 1200 & $1200^{\circ}$ & 650 & 1400 & 650 \\
\hline 10 Tairan & $1400 \mid$ & 6,50 & 400 & 1200 & $4(00)$ & 1200 & 650 & 1200 & 900 & 1000 & 900 & 900 & 1800 & 1200 & 400 & 1400 & 900 \\
\hline 11 Kaohsiung & 1400 & 900 & $400^{\circ}$ & 1400 & 400 & 1400 & 650 & 1400 & 1000 & 1200 & 1000 & 1000 & 1400 & 1400 & $40 f)$ & 1200 & 1000 \\
\hline 12 Pingtung & 1400 & 900 & 400 & 1400 & 400 & 1400 & 650 & $|1400|$ & 1000 & 1200 & 1000 & 1000 & 1400 & 1400 & 400 & 1200 & 1000 \\
\hline 13 Taitung & 1400 & 1400 & 1200 & 1400 & 1400 & 1400 & 1400 & 1400 & 1400 & 1400 & 1400 & 1400 & 1400 & 1400 & 1200 & i) & 1400 \\
\hline 14 Hwalien & 1400 & 1400 & 1400 & 1400 & 1400 & 1400 & 1400 & 1400 & 1200 & 1400 & 1200 & 1200 & 1400 & 1400 & 1400 & 1200 & 1200 \\
\hline
\end{tabular}

\begin{tabular}{|c|c|c|c|c|c|c|c|c|c|c|c|c|c|c|c|c|}
\hline AreáHsipl\} & 18 & 19 & 20 & 21 & 22 & 23 & 24 & 25 & 26 & 27 & 28 & 29 & 30 & 31 & 32 & 33 \\
\hline 1 Taipei & 1000 & 1400 & 1400 & 1200 & 1400 & 1000 & 1400 & 1000 & 400 & 6500 & 1400 & 10000 & 1000 & 1000 & 900 & 1400 \\
\hline 2 Taoy & 900 & 1400 & 1400 & 1000 & 1400 & 900 & 1400 & 900 & 400 & 630 & 1400 & 900 & 900 & 1000 & 50 & 1400 \\
\hline $3 \mathrm{Hsi}$ & 6000 & 1200 & 1200 & 900 & 1400 & 650 & 1400 & 650 & 650 & 400 & 1200 & 650 & 650 & 900 & 400 & 1200 \\
\hline 4 Miaoli & 650 & 1200 & 1200 & 900 & 1400 & 650 & 1400 & 650 & 900 & 400 & 1200 & 650 & 650 & 900 & 400 & 1200 \\
\hline 5 Taichung & 400 & 1000 & 1000 & 650 & 1200 & 400 & 1200 & 400 & 1000 & 650 & 10000 & 400 & 400 & 650 & 650 & 1000 \\
\hline 6 Changhwa & 400 & 1000 & 1000 & 400 & 1400 & 400 & 1400 & 400 & 1000 & 650 & 1000 & 400 & 400 & 650 & 650 & 1000 \\
\hline $7 \mathrm{~N}$ & $6 \breve{00}$ & 1000 & 1200 & 400 & 1400 & 650 & 1400 & 650 & 1000 & 900 & 1000 & 650 & 650 & 400 & 990 & 1000 \\
\hline 8 Yunlin & 400 & 900 & 900 & 400 & 1400 & 650 & 1400 & 400 & 1200 & 900 & 900 & 650 & 400 & 400 & 900 & 900 \\
\hline $9 \mathrm{C}$ & 650 & 650 & 650 & 400 & 1400 & 650 & 1400 & 650 & 1200 & 1000 & 650 & 650 & 650 & 650 & 900 & 650 \\
\hline $10^{\prime}$ & 900 & 400 & 400 & 650 & 1400 & 900 & 1400 & 900 & 1400 & 1200 & 400 & 900 & 900 & 900 & 1000 & 400 \\
\hline ohsilung & 1000 & 400 & 400 & 900 & 1200 & 1000 & 1200 & 1000 & 1400 & 1200 & 400 & 1000 & 1000 & 1000 & 1200 & 400 \\
\hline $12 \mathrm{P}$ & 1000 & 400 & 400 & 900 & 1200 & 1000 & 1200 & 1000 & 1400 & 1200 & 400 & 1000 & 1000 & 1200 & 1200 & 400 \\
\hline $13 \mathrm{~T}$ & 1400 & 1200 & 1200 & 1400 & 1200 & 1400 & 1200 & 1400 & 1400 & 1400 & 1200 & 1400 & 1400 & 1400 & 1400 & 1200 \\
\hline 14 Hwalien & 1400 & 1400 & 1400 & 1400 & & 12010 & & 1400 & 1400 & 1400 & 1400 & 1200 & 1400 & 1400 & 1400 & 1400 \\
\hline
\end{tabular}

Source: 1998 Taiwan Walking Internet, for data of road distances.

The data of unit transportation cost is through factories survey.

"The number from 1 to 33 represents the factories, here we do not include the name of factory (company) becalise of privacy.

When the factory is in the same place of supply area (factory owns its own dairy farms) we consider that the unit raw milk transportation cost is " 0 ".

way accorting to above conditions as well as leading to the problem of factory's relocation.

One more problem should be considered is regarding the liberalization of fluid milk trade. If the price of raw milk rise constantly as we forecast, accompanying the pressure of liberalization and international compctition, it may stimulate the import of fluid milk. Therefore, it should be another important issue that what kind of effects on dairy industrial organization in Taiwan will be under the liberalized fluid milk market in future, such as how much of raw milk demand and supply will decrease and how the raw milk price will drop down and so on. 
Table 11. Equilibrium raw milk trade flows and priees in 1996 under perfectly competitive spatial cquilibrium

Unit: ton and $\mathrm{NT} \$ / \mathrm{kg}$
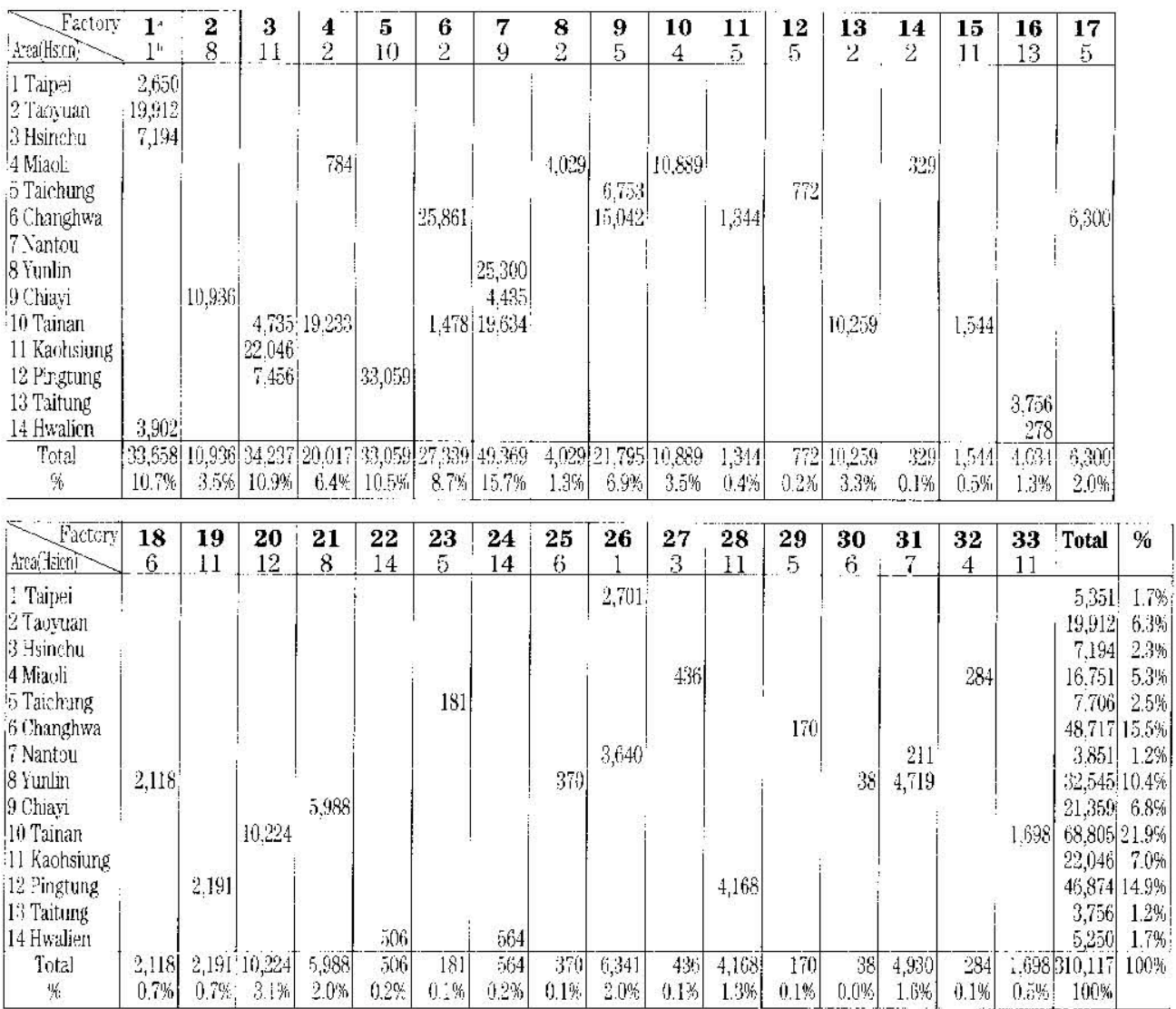

\begin{tabular}{lllllllllllllll}
\hline Supply Regions & 1 & 2 & 3 & 4 & 5 & 6 & 7 & 8 & 9 & 19 & 11 & 12 & 13 & 14
\end{tabular}

$\begin{array}{lllllllllllllll}\text { Pouled Price } & 19.65 & 19.66 & 19.4 & 19.35 & 19.11 & 19 . \mathrm{i} & 19.09 & 19.1 & 2906 & 18.81 & 18.8 & 18.8 & 19.86 & 18.7\end{array}$

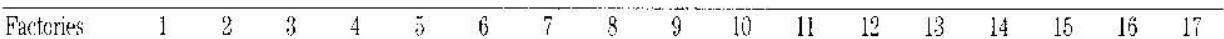

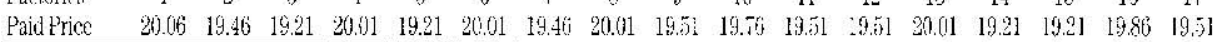

\begin{tabular}{lllllllllllllllll}
\hline Factories & 18 & 19 & 20 & 21 & 22 & 23 & 2 & 25 & 26 & 27 & 28 & 29 & 30 & 31 & 32 & 33
\end{tabular}

$\begin{array}{lllllllllllllllll}\text { Padd Price, } & 19.46 & 19.21 & 19.21 & 19.46 & 18.66 & 19.51 & 18.56 & 19.46 & 20.01 & 19.76 & 19.21 & 19.51 & 19.46 & 19.46 & 19.76 & 19.21\end{array}$

- The number from 1 to 33 represents the factories, here we do not include the name of factories (company) because of privacy.

- The number in this raw indicates the area which lactory is located in, and same as the number represented in the coluru of Area.

- The number of area from 1 to 4 indicates the north of Taiwar.

The number of area from 5 to 9 indicates the midde of Taiwan.

The number of area from 10 to 12 indicates the south of Taiwan.

The number of area from 13 to 14 indicates the east of Taiwan. 


\begin{tabular}{|c|c|c|c|c|c|c|c|c|c|c|c|c|c|c|c|c|c|c|c|c|c|c|c|}
\hline Year & 1 & 2 & 3 & 4 & 5 & 6 & 7 & 8 & 9 & 10 & 11 & 12 & 13 & 14 & 15 & 16 & 17 & 18 & 19 \\
\hline 2001 & 40,119 & 12,986 & 40,590 & 23,850 & 39,211 & 32,575 & 58,638 & 4,801 & 25,887 & 12,954 & 1,596 & 917 & 12,223 & 392 & 1,830 & 4,803 & 7,484 & 2,515 & 2,598 \\
2006 & 48,627 & 15,663 & 48,891 & 28,850 & 44,234 & 39,402 & 70,726 & 5,807 & 31,234 & 15,654 & 1,926 & 1,106 & 14,786 & 474 & 2,205 & 5,811 & 9,029 & 3,033 & 3,130 \\
2011 & 59,142 & 18,999 & 59,232 & 35,096 & 57,260 & 47,935 & 85,833 & 7,064 & 37,892 & 19,011 & 2,337 & 1,341 & 17,987 & 576 & 2,672 & 7,064 & 10,956 & 3,679 & 3,793 \\
2016 & 72,839 & 23,345 & 72,703 & 43,223 & 70,301 & 59,033 & 105,483 & 8,700 & 46,566 & 23,388 & 2,872 & 1,647 & 22,152 & 710 & 3,280 & 8,745 & 13,465 & 4,521 & 4,656 \\
\hline
\end{tabular}

\begin{tabular}{|c|c|c|c|c|c|c|c|c|c|c|c|c|c|c|c|}
\hline Year & 20 & 21 & 22 & 23 & 24 & 25 & 26 & 27 & 28 & 29 & 30 & 31 & 32 & 33 & Total \\
\hline 200 & 12,128 & 7,109 & 598 & 215 & 666 & 440 & 7,557 & 519 & 4,943 & 202 & 45 & 5,855 & 337 & 2,013 & 96 \\
\hline $20 r$ & 9 & 8,5 & $71 !$ & $2 i$ & 80 & Si & & 627 & & & 4 & & 407 & 5 & \\
\hline 201 & 17. & 10,398 & 80 & 31 & 96 & 643 & 11,1 & 102 & 7,2 & 296 & 66 & 8,2 & 4920 & 2,939 & 52 \\
\hline 2016 & 21,750 & 12,774 & 1,063 & 386 & 1,182 & 790 & 13,715 & 937 & 8,859 & 363 & 81 & 10,528 & 609 & 3,608 & 664,2 \\
\hline
\end{tabular}

Tuble 13. Forecasted raw milk demand prices for 33 Taiwanese dairy lactories from the ycar of 2001 to 2016

Unit: NT\$/kg.

\begin{tabular}{|c|c|c|c|c|c|c|c|c|c|c|c|c|c|c|c|c|c|c|c|}
\hline Year & 1 & 2 & 3 & 4 & 5 & 6 & 7 & 8 & $\theta$ & 10 & 11 & 12 & $\overline{13}$ & 14 & 15 & 16 & 17 & 18 & 19 \\
\hline 2001 & 23.85 & 23.25 & 23.00 & 23.80 & 23.00 & 23.80 & 23.25 & 23.80 & 23.30 & 23.55 & 23.30 & 23.30 & 23.80 & 23.80 & 23.00 & 23.65 & 23.30 & 23.25 & 23.00 \\
\hline 2006 & 28.58 & 28.03 & 27.78 & 28.58 & 27.78 & 28.58 & 28.08 & 28.58 & 28.08 & 28.33 & 28.08 & 28.08 & 28.58 & 28.58 & 27.78 & 28.38 & 28.08 & 28.03 & 27.78 \\
\hline 2011 & 34.95 & 34.40 & 34.15 & 34.95 & 34.15 & 34.95 & 34.40 & 34.95 & 34.45 & 34.70 & 34.4 & 34.45 & 34.95 & 34.95 & 34.15 & 34. & 34.45 & 34.40 & 34.15 \\
\hline 2016 & 43.01 & 42.46 & 42.21 & 43.01 & 42.21 & 43.01 & 42.26 & 43.01 & 42.51 & 42.76 & $42 . \overline{0}$ & 42.5 & 43. & 43.01 & 42.21 & 42.43 & 42.51 & 42.46 & 42.21 \\
\hline Year & 20 & 21 & 22 & 23 & 24 & 25 & 26 & 27 & 28 & 29 & 30 & 31 & 32 & 33 & & & & & \\
\hline 2001 & 23.00 & 23.25 & 22.45 & 23.30 & 22.45 & 23.25 & 23.85 & 23.55 & 23.00 & 23.30 & 23.25 & 23.25 & 23.55 & 23.00 & & & & & \\
\hline 2006 & 27.78 & 28.03 & 27.18 & 28.08 & 27.18 & 28.03 & 28.58 & 28.33 & 27.78 & 28.08 & 28.03 & 28.03 & 28.33 & 27.78 & & & & & \\
\hline 2011 & 34.15 & 34.40 & 33.55 & 34.45 & 33.55 & 34.40 & 34.95 & 34.70 & 34.15 & 34.45 & 34.40 & 34.40 & 34.70 & 34.15 & & & & & \\
\hline
\end{tabular}

Table 14. Forecasted raw milk supply quantitics for 14 Taiwanese dairy supply regions from the year of 2001 to 2016

Init: ton

\begin{tabular}{|c|c|c|c|c|c|c|c|c|c|c|c|c|c|c|c|}
\hline Year & 1 & 2 & 3 & 4 & 5 & 6 & 7 & 8 & 9 & 10 & 11 & 12 & 13 & 14 & Total \\
\hline 2001 & 6,839 & 25,515 & 9,259 & 21,420 & 8,5337 & 54,047 & 4,269 & 36,117 & 23,655 & 83,869 & 26,863 & 57,112 & 4,595 & 6,499 & 368,596 \\
\hline 2006 & 8,691 & 32,488 & 11,830 & 27,293 & 9,583 & 60,751 & 4,794 & 40,610 & 26,544 & 102,820 & 32,922 & 69,989 & 5,639 & $8,05,4$ & 442,008 \\
\hline 2011 & 11,191 & 41,901 & 15,299 & 35,136 & 10,980 & 69,704 & 5,495 & 46,611 & 30,402 & 128,131 & 41,014 & 87,188 & 7,048 & 10,152 & 540,252 \\
\hline 2016 & 14,349 & 53,791 & 19,681 & $45,(045$ & 12,744 & 81,014 & 6,381 & 54,191 & 35,275 & 160,104 & 51,237 & 108,915 & 8,745 & 12,802 & 664,274 \\
\hline
\end{tabular}

Table 15. Forecasted raw milk supply prices for 14 Taiwanese dairy supply regions from the year of 2001 to 2016

Unit: NT $\$ / \mathrm{kg}$.

\begin{tabular}{|c|c|c|c|c|c|c|c|c|c|c|c|c|c|c|}
\hline Year & 1 & 2 & 3 & 4 & 5 & 6 & 7 & 8 & 9 & 10 & 11 & 12 & 13 & 14 \\
\hline 2011 & 34.55 & 34.55 & 34.30 & 34.30 & 34.05 & 34.05 & 34.00 & 34.00 & 34.00 & 33.75 & 33.75 & 33.75 & 34.75 & 33.55 \\
\hline
\end{tabular}


Table 16. Transition of raw milk demand in small-scale dairy factories

\begin{tabular}{|r|c|c|c|c|c|c|c|c|c|c|c|c|c|c|c|c|c|}
\hline & YP & AM & KS & ZK & KT & CC & HT & TC & SM & OS & SC & CF & DM & CS & CT & SF & CH \\
\hline 1992 & 2385 & 1836 & 1390 & 540 & 1359 & 328 & 743 & 1588 & 372 & 456 & 648 & 167 & 57 & 78 & 360 & - & - \\
1993 & 2298 & 1710 & 2338 & 431 & 1527 & - & - & 1206 & 147 & 402 & 588 & 194 & 56 & 427 & 1431 & - & 79 \\
1994 & 2282 & 1211 & 2299 & 432 & 1640 & - & - & 367 & 135 & 566 & 489 & 266 & 56 & 458 & 823 & 230 & 104 \\
1995 & 1664 & 532 & 1881 & 367 & 2007 & - & - & 588 & 148 & 585 & 448 & 353 & 30 & 163 & - & 440 & 97 \\
1996 & 1370 & 347 & 1547 & 187 & 2187 & - & - & 503 & 200 & 587 & 376 & 432 & - & - & - & 291 & 38 \\
1997 & 1449 & 342 & 1463 & 235 & 2280 & - & - & 126 & 202 & 639 & 497 & 443 & - & - & - & 426 & - \\
\hline
\end{tabular}

Source: same as in table 3

\section{REFERENCES}

Dantzig, G. B. 1949 Programming of Interdependent Activities, II, Mathematical Model. In "Activity Analysis of Production and Allocation". ed. by T. C. Koopmans, John Wiley and Sons, New York, 1951, pp. $19-32$

Durham, C. A., Sexton, R. J. and J. H. Song 1996 Spatial Competition, Uniform Pricing, and Transportation Ffficiency in the California Processing Tomato Industry. Amer. J. Agr. Econ., 78: $115-125$

Halvorson, Harlow W. 1955 The Supply Elasticity for Milk in the Short Run. J. Farm Econ., 37-II (1955): 1186-1197

Harker, Patrick T. 1986 Alternative Models of Spatial Competition. Operations Research, 34-3 (May-June 1986): 410-425

Hashimoto, H. 1985 A Spatial Nash Equilibrium Model. In "Spatial Price Equilibrium: Advances in Theory, Computation and Application (Lecture Notes in Economics and Mathematical Systems Vol. 249)", ed. by P. T. IIarker, Springer-Verlag, Berlin Heidelberg, pp. 20-40

Hayenga, Marvin L. and Duane Hacklander 1970 Monthly Supply-Demand Relationships for Fed Cattle and Hogs. Am. J. Agr. Econ, 52-4: 535-544

Kawaguchi, T., Suzıki, N., and H. M. Kaiser 1997 A Spatial Equilibrium Model for Imperfectly Competitive Milk Markets. Am. J. Agr. Econ, 79: 851-859

Koopmans, T. C. 1949 Optimum Utilization of the Transportation System. Ecomometrica (Supplement), 17: $136-146$

Kottke, Marvin 1970 Spatial, Temporal and Product-Use Allocation of Milk in an Imperfectly Competitive Dairy Industry. Am. J. Agr. Econ. 52-1: 33-40

Kuhn, H. W. and A. W. Tucker 1951 Nonlinear Programming. In "Proceedings of the Second Berkely Symposium on Mathematical Statistics and Probabilities". ed. by J. Neyman, University of California Press, California, pp. 481-492

Ladd, George W, and George R. Winter 1961 Supply of Dairy Products by Iowa Farmers, J. Farm Econ., 43-I: $113-122$

Levins, Richard A. 1982 Price Specification in Milk Supply Response Analysis. Am. J. Agr. Econ., 64-2: $286-288$

Lin, Lily and T. Kawaguchi 1998 Study on Reducing Raw Milk Transportation Cost in Taiwanese Dairy Industry. J. Fac. Agr., Kyushu Univ., 43(1·2): 269-280, Nov. 1998

Lio, Iluei Ming 1997 The introduction of producing and marketing situation in Taiwanese fluid milk industry. Food Marketing News, 8607: 10-12 (in Chinese)

Lio, Yao Chung 1996 An ecomomic analysis of dairy farmer's milk production cost in Taiwan. MA Thesis. National Chung Hsing University, Taiwan (in Chinese)

Milligan, Robert A. 1978 Milk Supply Response in California: Effects of Profitability Variables and Regional Characteristics. West. J. Agr. Econ., 3: 157-164

Nerlove, Marc 1956 Estimate of the Elasticities of Supply of Selected Agricuitural Commodities. $J$. Farm Econ., 38: 496-509

Nerlove, Marc 1979 The Dynamics of Supply: retrospect and Prospect Am. J. Agr. Econ., 61-3: $874-888$ 
Rockafellar, R. T. 1980 Lagrange Multipliers and Variational Inequalities. In "Variational Inequalities and Complementarity Problems-Theory and Applications". ed. by R. W. Cottle et. al., John Wiley, pp. 303-322

Samuelson, P. A. 1952 Spatial Price Equilibrium and Linear Programming. The American Economic Review, 42: 283-303

Takayama, T. and G. G. Judge 1964 Spatial Equilibrium and Quadratic Programming. J. Farm Econ., 46: $67-93$

Takayma, T. and G. G. Judge 1971 Spatial and Temporal Price and Allocation Models. North Holland Publishing Co., Amsterdam. 